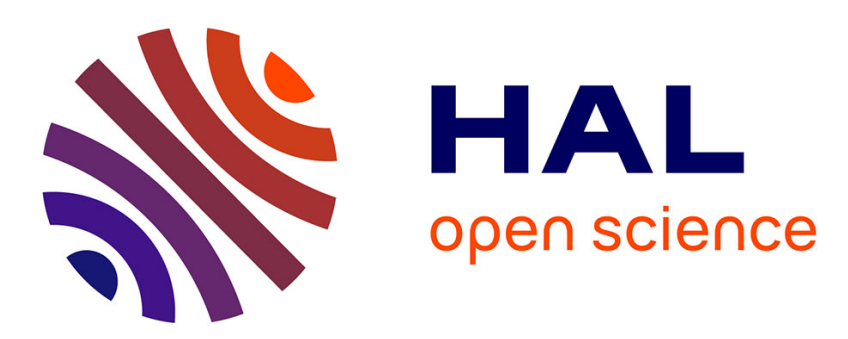

\title{
Towards a full accounting of the greenhouse gas balance of European Grasslands
}

Jean-François J.-F. Soussana

\section{To cite this version:}

Jean-François J.-F. Soussana. Towards a full accounting of the greenhouse gas balance of European Grasslands. The Continental-Scale Greenhouse Gas Balance of Europe, 203, Ecological Series, Springer, 2008, Ecological Series, 978-0-387-76568-6. hal-02813210

\section{HAL Id: hal-02813210 \\ https://hal.inrae.fr/hal-02813210}

Submitted on 6 Jun 2020

HAL is a multi-disciplinary open access archive for the deposit and dissemination of scientific research documents, whether they are published or not. The documents may come from teaching and research institutions in France or abroad, or from public or private research centers.
L'archive ouverte pluridisciplinaire HAL, est destinée au dépôt et à la diffusion de documents scientifiques de niveau recherche, publiés ou non, émanant des établissements d'enseignement et de recherche français ou étrangers, des laboratoires publics ou privés. 


\title{
Chapter 13 \\ Towards a Full Accounting of the Greenhouse Gas Balance of European Grasslands
}

\author{
Jean-François Soussana
}

\subsection{Introduction}

Pastures and livestock production systems are extremely diverse. They occur in a large range of climate and soil conditions and range from very extensive pastoral systems, where domestic herbivores graze and browse rangelands, to intensive systems based on forage and grain crops, where animals are mostly kept indoors. On a global scale, livestock use 3.4 billion ha of grazing land, in addition to animal feed produced on about a quarter of the land under crops (Delgado 2005). Grasslands and pastures contribute to the livelihoods of over 800 million people including many poor smallholders (Reynolds et al. 2005). By 2020, this agricultural sub-sector will produce about $30 \%$ of the value of global agricultural output (Delgado 2005).

Pastures include both grasslands and rangelands. Grasslands are the natural climax vegetation in areas (e.g. the Steppes of central Asia and the prairies of North America) where the rainfall is low enough to prevent the growth of forests. In other areas, where rainfall is normally higher, grasslands do not form the climax vegetation (e.g. north-western and central Europe) and are more productive. Rangelands are characterised by low stature vegetation, due to temperature and moisture restrictions, and found on every continent. Worldwide the soil organic $\mathrm{C}$ sequestration potential is estimated to be $0.01-0.3 \mathrm{GtC}_{\text {year }}^{-1}$ on 3.7 billion ha of permanent pasture (Lal 2004). Thus, soil organic C sequestration by the world's permanent pastures could potentially offset up to $4 \%$ of the global greenhouse gas (GHG) emissions.

According to remote sensing data (CORINE LandCover and PELCOM; CORINE 1995, 2000), grasslands cover $20 \%$ of the area of the European continent and distribute about equally between western Europe ( $80 \mathrm{Mha}$ ) and eastern Europe (60 Mha). Within the area managed by agricultural practices on the European continent, $37 \%$ is devoted to grasslands (EEA 2005). Following the new membership of twelve countries, the EU 27 has an enlarged area of grassland of about 20 million ha (Carlier et al. 2004).

The GHG budget of European grasslands is still highly uncertain. There are only few continental scale modelling estimates of the GHG budget of grasslands, primarily 
focused on the $\mathrm{CO}_{2}$ component of the GHG budget. Vleeshouwers and Verhagen (2002), further quoted by Janssens et al. (2003), applied a semi-empirical model of land use induced soil carbon disturbances to the European continent (as far east as the Urals $)$ and inferred a carbon sink of $101 \mathrm{GtC}_{\text {year }}{ }^{-1}$ over grasslands $\left(0.52 \mathrm{tC} \mathrm{ha}^{-1}\right.$ year $^{-1}$ ) with uncertainties above the mean.

Managed European grasslands are often fertilised to sustain productivity and thus emit $\mathrm{N}_{2} \mathrm{O}$ to the atmosphere above the background level that is found in natural systems (Flechard et al. 2007). Typical $\mathrm{N}_{2} \mathrm{O}$ emissions from grassland soils, converted into $\mathrm{CO}_{2}$ equivalent sources on a 100 years time horizon (Bouwman 1996), range between 0.1 and 1 teqC ha $^{-1}$ year $^{-1}$ (Machefert et al. 2002; Sozanska et al. 2002). One recent estimate of $\mathrm{N}_{2} \mathrm{O}$ fluxes from grasslands indicates a mean emission of $2.0 \mathrm{~kg}$ $\mathrm{N}_{2} \mathrm{O}-\mathrm{N} \mathrm{ha}{ }^{-1}$ year $^{-1}$ in 2000 , which translates into $0.25 \mathrm{tCO}_{2}-\mathrm{C}$ equivalent ha ${ }^{-1}$ year $^{-1}$ (Freibauer et al. 2004).

European grasslands sustain an important number of domestic herbivores, 150 millions of cows and 150 millions of sheep, roughly $15 \%$ of the global animal population (FAO 2004). Grazers impact the cycling of $\mathrm{C}$ and $\mathrm{N}$ within pastures via defoliation, excretal returns and mechanical disturbance and emit $\mathrm{CO}_{2}$ via their metabolic activity. Ruminants also emit $\mathrm{CH}_{4}$ with range for annual emission from 0.05 to $0.25 \mathrm{tCH}_{4}(0.3-1.5$ teqC, Vermorel 1995).

Currently, the net global warming potential (GWP, in terms of $\mathrm{CO}_{2}$ equivalent) from the GHG exchanges with European grasslands is not known. It is clear that an integrated approach, that would allow to quantify the fluxes from all three radiatively active trace gases $\left(\mathrm{CO}_{2}, \mathrm{CH}_{4}, \mathrm{~N}_{2} \mathrm{O}\right)$, would be desirable. Management choices to reduce emissions involve important trade-offs: for example, preserving grasslands and adapting their management to improve carbon sequestration in the soil may actually increase $\mathrm{N}_{2} \mathrm{O}$ and $\mathrm{CH}_{4}$ emissions.

The Marrakech Accords, resulting from the 7th Conference of Parties (COP7) to the 1992 United Nations Framework Convention on Climate Change (UNFCCC), allow biospheric carbon sinks (and sources) to be included in attempts to meet Quantified Emission Limitation or Reduction Commitments (QELRCs) for the first commitment period (2008-2012) outlined in the Kyoto Protocol (available at: www.unfccc.de). Under Article 3.4, the following activities are included: forest management, cropland management, grazing land management and re-vegetation. Soil carbon sinks (and sources) can therefore be included under these activities. Further, direct emission reductions of the GHGs $\mathrm{N}_{2} \mathrm{O}$ and $\mathrm{CH}_{4}$ will help parties to meet QELRCs.

Since agricultural management is one of the key drivers of the sequestration and emission processes, there is a potential within the EU to reduce the net GHG flux for grasslands, expressed in $\mathrm{CO}_{2}$ equivalents. However, it is essential that effects of land management of all three GHGs are evaluated concomitantly.

Until recently, there were very few direct measurements of the GHG fluxes exchanged with grasslands with a sufficiently long-term continuity. A network of nine sites was established as part of the GreenGrass project starting in 2002 (European Commission DG Research Vth Framework Programme-Contract no. 
EVK2-CT2001-00105). Other flux sites were established within the 'CarboMont' (Cernusca 2004) and 'CarboEurope IP' (CarboEurope 2003) projects.

Here we review the characteristics which would allow monitoring the GHG balance of European grasslands with sufficient accuracy. We first summarise the main features of the GHG balance in a grassland ecosystem. We then review recent results concerning the GHG balance at three complementary spatial scales: the field, the farm and the region. We finally discuss how to scale up by bottom-up modelling and/or inventories.

\subsection{The C Cycle and Non- $\mathrm{CO}_{2}$ Greenhouse Gas Emissions in Grassland Ecosystems}

\subsubsection{Carbon Cycling in Grasslands}

For grasslands, the nature, frequency and intensity of disturbance play a key role in the $\mathrm{C}$ balance. In a cutting regime, a large part of the primary production is exported from the plot as hay or silage, but part of these $C$ exports may be compensated for by farm manure and slurry application. Under intensive grazing, up to $60 \%$ of the above-ground dry matter production is ingested by domestic herbivores (Lemaire and Chapman 1996). However, this percentage can be much lower during extensive grazing. The largest part of the ingested carbon is digestible (up to $75 \%$ for highly digestible forages) and, hence, is respired shortly after intake. Only a small fraction of the ingested carbon is accumulated in the body of domestic herbivores or is exported as milk (Vermorel 1995).

Additional carbon losses (ca 5\% of the digestible carbon) occur through methane emissions from the enteric fermentation. The non-digestible carbon (25-40\% of the intake according to the digestibility of the grazed herbage) is returned to the pasture in excreta (mainly as faeces). In most European husbandry systems, the herbage digestibility tends to be maximised by agricultural practices such as frequent grazing and use of highly digestible forage cultivars. Consequently, the primary factor which modifies the carbon flux returned to the soil by excreta is the grazing pressure which varies with the annual stocking rate (mean number of livestock units per unit area). Secondary effects of grazing on the carbon cycle of a pasture include: (1) the role of excretal returns, concentrated in patches, for nutrients cycling, which could increase primary production up to a moderate rate of grazing intensity especially in nutrient-poor grasslands (De Mazancourt et al. 1998) and (2) the role of defoliation by animals and of treading both of which reduce the leaf area.

Organic matter is partly incorporated in grassland soils through rhizodeposition (Jones and Donnelly 2004). This process favours carbon storage (Balesdent and Balabane 1996), because direct incorporation into the soil matrix allows a high degree of physical stabilisation of the soil organic matter. Soil carbon stocks display 
a high spatial variability (coefficient of variation of 50\%, Cannell et al. 1999) in grassland as compared to arable land and ca $15 \%$ of this variability comes from sampling to different depths (Robles and Burke 1998; Chevallier et al. 2000; Bird et al. 2002).

The Intergovernmental Panel on Climate Change (IPCC) report dealing with this issue (IPCC 2004) provides estimates for the grassland management on SOC storage based on a literature review and meta-analysis of grassland studies (Conant et al. 2001). According to those findings, land use change from grassland to cropland systems causes losses of SOC in temperate regions ranging from $18 \%( \pm 4)$ in dry climates to $29 \%( \pm 4)$ in moist climates. Converting cropland back to grassland uses for 20 years was found to restore $18 \%( \pm 7)$ of the native carbon stocks in moist climates (relative to the $29 \%$ loss due to long-term cultivation) and $7 \%( \pm 5)$ of native stocks in temperate dry climates.

Based on the IPCC method for classifying management systems (IPCC 2004), grassland practices are categorised as improved (e.g. sowing legumes, irrigation, fertilisation and planting more productive forage species) or degraded (e.g. overgrazing and planting less productive species relative to native vegetation). Grasslands that are degraded for 20 years typically have 5\% $( \pm 6)$ less carbon than native systems in tropical regions and $3 \%( \pm 5)$ less carbon in temperate regions. Improving grasslands with a single practice caused a relatively large gain in SOC over 20 years, estimated as $14 \%( \pm 6)$ in temperate regions and $17 \%$ $( \pm 5)$ in tropical regions, while having an additional improvement led to another $11 \%( \pm 5)$ increase in SOC (Ogle et al. 2004).

In Europe, most soils are out of equilibrium as they have been affected by a number of changes in land use/land management practices during the past 100 years. Management practices affecting soil organic $\mathrm{C}$ stocks in grassland areas include changes between arable and grassland, grassland and forest, grassland management such as tillage (sown grasslands), grazing and cutting management, inorganic and organic fertiliser use, legumes, the type of fertiliser applied and water management.

As a result of periodic tillage and resowing, short duration grasslands tend to have a potential for soil carbon storage intermediate between crops and permanent grassland. Part of the additional carbon stored in the soil during the grassland phase is released when the grassland is ploughed up. The mean carbon storage increases in line with prolonging the lifespan of covers, that is less frequent ploughing (Soussana et al. 2004a).

In France, average soil $(0-30 \mathrm{~cm})$ organic $\mathrm{C}$ stocks are lower than $45 \mathrm{tC} \mathrm{ha}^{-1}$ for arable land and reach nearly $70 \mathrm{tC} \mathrm{ha}^{-1}$ for land under permanent grassland and forests (excluding litter). Based on this inventory, the average difference between cropland and pastures is ca $25 \mathrm{tC} \mathrm{ha}^{-1}$. This value represents the range of carbon change involved in land use conversions. Changes in soil carbon through time are non-linear after a change in land use or in grassland management. A simple two parameters model has been used to estimate the magnitude of the soil carbon stock change after a change in grassland management (INRA 2002; Soussana et al. 2004b). 


\subsection{2 $\mathrm{N}_{2} \mathrm{O}$ Emissions from Soils}

Biogenic emissions of $\mathrm{N}_{2} \mathrm{O}$ from soils result primarily from the microbial processes nitrification and denitrification. $\mathrm{N}_{2} \mathrm{O}$ is a by-product of nitrification and an intermediate during denitrification. Nitrification is the aerobic microbial oxidation of ammonium to nitrate and denitrification is the anaerobic microbial reduction of nitrate through nitrite, nitric oxide (NO) and $\mathrm{N}_{2} \mathrm{O}$ to $\mathrm{N}_{2}$. Nitrous oxide is a gaseous product that may be released from both processes to the soil atmosphere.

Major environmental regulators of these processes are temperature, $\mathrm{pH}$, soil moisture (i.e. oxygen availability) and carbon availability (Velthof and Oenema 1997). In most agricultural soils, biogenic formation of $\mathrm{N}_{2} \mathrm{O}$ is enhanced by an increase in available mineral nitrogen, which in turn increases nitrification and denitrification rates. Hence, in general, addition of fertiliser $\mathrm{N}$ or manures and wastes containing inorganic or readily mineralisable $\mathrm{N}$ will stimulate $\mathrm{N}_{2} \mathrm{O}$ emission as modified by soil conditions at the time of application. $\mathrm{N}_{2} \mathrm{O}$ losses under anaerobic conditions are usually considered more important than nitrification- $\mathrm{N}_{2} \mathrm{O}$ losses under aerobic conditions. At a global scale, soils account for $65 \%$ of $\mathrm{N}_{2} \mathrm{O}$ emissions (IPCC 1996b). For given soil and climate conditions, $\mathrm{N}_{2} \mathrm{O}$ emissions are likely to scale with the nitrogen fertiliser inputs. Therefore, the current IPCC (1996a) methodology assumes a default emission factor $\left(\mathrm{EF}_{1}\right)$ of $1.25 \%$ (range $0.25-2.25 \%$ ) for non-tropical soils emitted as $\mathrm{N}_{2} \mathrm{O}$ per unit nitrogen input $\mathrm{N}(0.0025-0.0225 \mathrm{~kg}$ $\mathrm{N}_{2} \mathrm{O}-\mathrm{N} \mathrm{kg}^{-1} \mathrm{~N}$ input).

$\mathrm{N}_{2} \mathrm{O}$ emissions in soils usually occur in 'hot spots' associated with urine spots and particles of residues and fertiliser, despite the diffuse spreading of fertilisers and manure (Flechard et al. 2007). Nitrous oxide emissions from grasslands tend also to occur in short-lived bursts following the application of fertilisers (Leahy et al. 2004; Clayton et al. 1997). Temporal and spatial variations contribute large sources of uncertainty in $\mathrm{N}_{2} \mathrm{O}$ fluxes at the field and annual scales (Flechard et al. 2005). The overall uncertainty in annual flux estimates derived from chamber measurements may be as high as $50 \%$ due to the temporal and spatial variability in fluxes, which warrants the future use of continuous measurements, if possible at the field scale (Flechard et al. 2007). In the same study, annual emission factors for fertilized systems were highly variable, but the mean emission factor $(0.75 \%)$ was substantially lower than the IPCC default value of $1.25 \%$ (Flechard et al. 2007).

\subsection{3 $\mathrm{CH}_{4}$ Fluxes Exchanged with Soils and Vegetation}

In soils, methane is formed under anaerobic conditions at the end of the reduction chain when all other electron acceptors, such as, for example nitrate and sulphate, have been used. Methane emissions from freely drained grassland soils are, therefore, negligible. In fact, aerobic grassland soils tend to oxidise methane at a larger rate than cropland soil ( 6 and $3 \mathrm{~kg} \mathrm{CH}_{4} \mathrm{ha}^{-1}$ year $^{-1}$, respectively), but less so than 
uncultivated soils (Boeckx and Van Cleemput 2001). For drained grasslands, methane oxidation was estimated between 0.1 and $1.1 \mathrm{~kg} \mathrm{CH}_{4} \mathrm{ha}^{-1}$ year $^{-1}$ (Van Den PolVan Dasselaar 1998). In contrast, in wet grasslands as in wetlands, the development of anaerobic conditions in soils may lead to methane emissions.

Keppler et al. (2006) have shown the emissions of low amounts of $\mathrm{CH}_{4}$ by terrestrial plants under aerobic conditions. However, this claim has not been confirmed and could be due to an experimental artefact (Dueck et al. 2007). In an abandoned peat meadow, methane emissions were lower in water unsaturated compared to water saturated soil conditions (Hendriks et al. 2007).

\subsection{4 $\mathrm{CH}_{4}$ Fluxes from Enteric Fermentation}

Enteric emissions in the world and the EU-15 have been estimated to 60-80 and $7-10 \mathrm{Gt}$ year $^{-1}$ respectively, and contribute around $18 \%$ and $29 \%$ of total methane emissions, respectively. The enteric methane plays a greater part to total methane emissions in EU than in the world (29\% vs. 18\%). The direct contribution of enteric methane to the total greenhouse effect has been estimated to 2-3\%. Enteric methane emissions tended to stabilise during the last decade at the world level, or even decreased in EU-15. Such a decline within the EU is explained by a reduction of the number of animals and intensification of animal production following the reform of the European CAP. Ruminants are the major methane producers since they account for $95 \%$ of the total animal enteric methane emissions. The emissions of methane by ruminants contribute between $16 \%$ and $23 \%$ of the global emissions of this gas (IPCC 1996b).

The emissions of methane by ruminants are due to the fermentative reactions in the digestive tract, called enteric fermentation. The rumen is a large anaerobic fermentative chamber located at the beginning of the digestive tract of ruminants, which contributes $70 \%$ of total organic matter digestion. Enzymes involved in ruminal digestion are solely of microbial origin. Every day a cow produces 300 7001 of methane. The annual emissions of $\mathrm{CH}_{4}$ originating from enteric fermentation are typically between 80 and $100 \mathrm{~kg}$ per animal per year for dairy cattle in Europe (IPCC 1996a), leading to annual emissions equivalent to $0.67-0.84 \mathrm{tC}$ per animal as $\mathrm{CO}_{2}$ equivalent.

The $\mathrm{CH}_{4}$ emissions by cattle depend upon the type, age and weight of the animal and the quantity and quality of the feed consumed. Methane emission is positively correlated to the amount of fermented organic matter in the rumen and the intake of digestible energy (Blaxter and Clapperton 1965). It increases with the amount of feed intake but, for the same diet, the proportion of gross energy lost in methane decreases with intake level. Large variations exist in methanogenic power of ingredients and diets. Methane production is closely related to the amount of dietary digestible cellulose content (Pinares-Patino et al. 2003), whereas it decreases with addition of concentrate at a level higher than $30 \%$ in the diet (Giger-Reverdin et al. 2000). 
Under grazing conditions, most of the variability in the enteric methane production of grassland plots lies in the number of animals, and, therefore, the emissions per unit land area will primarily vary with the stocking rate (Pinares-Patino et al. 2007, Soussana et al. 2007). The methane emission rate per unit liveweight (LW) varies also markedly at grazing between different animal types. This rate, measured with the SF6 dual tracer technique (Johnson et al. 1994), was comprised between 0.33 and $0.45 \mathrm{~g} \mathrm{CH}_{4} \mathrm{~kg}^{-1} \mathrm{LW} \mathrm{day}{ }^{-1}$ for heifers and bulls and reached $0.68-0.97 \mathrm{~g}$ $\mathrm{CH}_{4} \mathrm{~kg}^{-1} \mathrm{LW} \mathrm{day}{ }^{-1}$ for lactating cows (LE) (Soussana et al. 2007).

The impact of belched $\mathrm{CO}_{2}$ (digestive + metabolic $\mathrm{CO}_{2}$ ) on warming effect has not been considered until now as significant. Using the SF6 method and taking into account the GWP of each gas and their quantitative emissions, the warming $\mathrm{CO}_{2} / \mathrm{CH}_{4}$ ratio for various animal types has been calculated at grazing. It varies from 1.1 for low-producing dairy cows (Pinares-Patino et al. 2007) to 1.8 for dry cattle. $\mathrm{CO}_{2}$ emission from cattle has not been taken into account by the IPCC because it is 'short-cycling' carbon, which has been fixed by the plants earlier and has thus no effect on atmospheric concentrations. However, it should be noted that importing animal feed leads to trans-boundary fluxes of carbon and to additional $\mathrm{CO}_{2}$ emissions in the importing country.

\subsubsection{Emissions During Housing: Manures and Livestock Wastes}

On-farm emissions from animals and manure must be taken into account when the GHG mitigation potential of grassland management strategies involving grazing is evaluated. GHG emissions from manure management include direct emissions of $\mathrm{CH}_{4}$ and $\mathrm{N}_{2} \mathrm{O}$, as well as indirect emissions of $\mathrm{N}_{2} \mathrm{O}$ derived from $\mathrm{NH}_{3} / \mathrm{NO}_{x}$. Quantification of GHG emissions from manure are typically based on national statistics for manure production and housing systems combined with emission factors which have been defined by the IPCC or nationally. The quality of GHG inventories for manure management is critically dependent on the applicability of these emission factors.

Animal manure is collected as solid manure and urine, as liquid manure (slurry) or as deep litter, or it is deposited outside in drylots or on pastures. These manure categories represent very different potentials for GHG emissions, as also reflected in the methane conversion factors and nitrous oxide emission factors, respectively. However, even within each category, the variations in manure composition and storage conditions can lead to highly variable emissions in practice. This variability is a major source of error in the quantification of the GHG balance for a system. To the extent that such variability is influenced by management and/or local climatic conditions, it may be possible to improve the procedures for estimating $\mathrm{CH}_{4}$ and $\mathrm{N}_{2} \mathrm{O}$ emissions from manure (Sommer et al. 2004).

Excreta (dung and urine) deposited during grazing influences fluxes of $\mathrm{CH}_{4}$, $\mathrm{N}_{2} \mathrm{O}$ and $\mathrm{NH}_{3}$ from the pasture. In particular, urine patches are important point 
sources of $\mathrm{NH}_{3}$ and $\mathrm{N}_{2} \mathrm{O}$, whereas the $\mathrm{N}$ input may locally reduce $\mathrm{CH}_{4}$ oxidation activity. Ammonia losses from pastures are not specifically represented in the IPCC methodology, which calculates $\mathrm{NH}_{3}$ volatilisation as a fixed proportion of total $\mathrm{N}$ excreted. However, ammonia losses from excretal returns to the pasture increase with $\mathrm{N}$ surplus in the diet since this $\mathrm{N}$ is mainly excreted as urea in the urine.

\subsubsection{Greenhouse Gas Balance}

When assessing the impact of land use and land use change on GHG emissions, it is important to consider the impacts on all GHGs (Robertson et al. 2000; Smith et al. 2001). $\mathrm{N}_{2} \mathrm{O}$ and $\mathrm{CH}_{4}$ emissions are often expressed in terms of $\mathrm{CO}_{2}$ or $\mathrm{CO}_{2}-\mathrm{C}$ equivalents, which is possible because the radiative forcing of nitrous oxide, methane and carbon dioxide, can be integrated over different timescales and compared to that for $\mathrm{CO}_{2}$.

For example, over the 100-year timescale, 1 unit of nitrous oxide has the same GWP as 310 units of carbon dioxide, whereas, on a kilogram for kilogram basis, 1 unit of methane has the same GWP as 21 units of carbon dioxide (IPCC 2001a). An integrated approach is needed to quantify in $\mathrm{CO}_{2}-\mathrm{C}$ equivalents the fluxes of all three trace gases $\left(\mathrm{CO}_{2}, \mathrm{CH}_{4}\right.$ and $\left.\mathrm{N}_{2} \mathrm{O}\right)$.

\subsection{Carbon and Greenhouse Gas Balance of Grasslands in Europe}

\subsubsection{Methodological Issues}

$\mathrm{CO}_{2}$ fluxes exchanged by grasslands were initially measured in enclosure systems (e.g. Paustian et al. 1990; Casella and Soussana 1997; Aeschlimann et al. 2005). However, given the large spatial variability of the vegetation and the microclimatic artefacts created by enclosures, the results from such experiments were difficult to extrapolate at the field scale. With the advancement of micrometeorological studies of the ecosystem-scale $\mathrm{CO}_{2}$ exchange (Baldocchi et al. 1996; Baldocchi and Meyers 1998), eddy flux covariance measurement techniques have been applied to grassland and rangelands. In Europe, the proportion of grassland sites in the flux tower network now roughly matches the proportion of the land surface covered by grasslands (CarboEurope IP 2003).

Eddy covariance measurements integrate fluxes over a large area and are therefore very relevant for estimating net ecosystem exchange (NEE) over heterogeneous covers such as pastures. Moreover, since the measurement uses a free air technique, as opposed to enclosures, there is no disturbance of the measured area which can be freely accessed by herbivores. However, eddy covariance techniques may encounter some specific problems when used in grasslands and rangelands. 
In Europe most managed grasslands are divided at the landscape scale in a large number of relatively small (often $<1$ ha) paddocks, each paddock being managed differently by farmers, through grazing, cutting and fertiliser applications. Footprint models are required to separate the fluxes among the paddocks which adds to the uncertainties involved in the calculation of the annual NEE at this scale. By contrast, the large paddock size usually found in rangelands and extensive grasslands is better suited to eddy covariance measurements.

Large domestic herbivores form mobile point sources of $\mathrm{CO}_{2}$. As long as the herbivores are within the footprint of the sensors, the belched $\mathrm{CO}_{2}$ will be rapidly diluted in the background air and transported by turbulence to the sensors. However, when grazers are very close to the sensors, they tend to create $\mathrm{CO}_{2}$ spikes that may be rejected when filtering the data. Therefore, in order to account for the herbivore's $\mathrm{CO}_{2}$ emissions at grazing two conditions need to be fulfilled: a random distribution of the herbivores within the measured paddock and a minimum distance (a few metres or more) between the herbivores and the sensors.

\subsubsection{Net Ecosystem Exchange and Atmospheric $\mathrm{CO}_{2}$ Balance of European Grasslands}

Gilmanov et al. (2007) have analysed tower $\mathrm{CO}_{2}$ flux measurements from 20 European grasslands covering a wide range of environmental and management conditions. Annual net ecosystem $\mathrm{CO}_{2}$ exchange (NEE) varies from significant net uptake $\left(>2400 \mathrm{~g} \mathrm{CO}_{2} \mathrm{~m}^{-2}\right.$ year $\left.^{-1}\right)$ to significant release $\left(<-600 \mathrm{~g} \mathrm{CO}_{2} \mathrm{~m}^{-2}\right.$ year $\left.^{-1}\right)$, though in 15 of 19 cases grasslands performed as net $\mathrm{CO}_{2}$ sinks. The carbon source was associated with organic rich soils, grazing and heat stress. Maxima of gross primary productivity (GPP) and ecosystem respiration (RE) were found in intensively managed grasslands of Atlantic climate. Extensively used semi-natural grasslands of southern and central Europe had much lower production, respiration and light-use efficiency, while temperate and mountain grasslands of central Europe ranged between these two extremes. Gross primary production (GPP) of European grasslands ranges from $1,700 \mathrm{~g} \mathrm{CO}_{2} \mathrm{~m}^{-2}$ year $^{-1}$ in dry semi-natural pastures to $6,900 \mathrm{~g} \mathrm{CO}_{2} \mathrm{~m}^{-2}$ year $^{-1}$ in intensively managed Atlantic grasslands. Ecosystem respiration was in the range $1,800-6,000 \mathrm{~g} \mathrm{CO}_{2} \mathrm{~m}^{-2}$ year $^{-1}$ (Gilmanov et al. 2007).

Janssens et al. (2003) concluded that European grasslands may constitute a net $\mathrm{C}$ sink $\left(-60 \pm 80 \mathrm{~g} \mathrm{C} \mathrm{m}^{-2}\right.$ year $\left.^{-1}\right)$, although the uncertainty surrounding this estimate was larger than the sink itself. On average of nine grassland sites, Soussana et al. (2007) have shown that grassland NEE displayed a significant atmospheric $(n=9$, sign test, $p<0.01$ ) sink activity for $\mathrm{CO}_{2}$. The magnitude of the sink was higher than the mean estimate by Janssens et al. (2003). With an extended data set covering 20 European grassland sites, Gilmanov et al. (2007) show that 4 sites became C sources in some years, 2 of them during drought events and 2 of them with a significant peat horizon. These findings for European grasslands confirm earlier estimates for North America (Follett 2001) that these ecosystems predominantly act as a sink for atmospheric $\mathrm{CO}_{2}$. 
Nevertheless, as shown by Ciais et al. (2005), the $\mathrm{CO}_{2}$ sink activity can turn to a source during summer heat waves, which affect both gross photosynthesis and total ecosystem respiration. Gilmanov et al. (2005) have also shown that a source type of activity is not an exception for the mixed prairie ecosystems in North America, especially during years with lower than normal precipitation.

\subsubsection{Net Biome Productivity}

In grazed-only systems (not supplied with manures), NEE is a good proxy of net C storage. Plant biomass is digested on site by the herbivore and this process contributes to the total ecosystem respiration that can be analysed from eddy covariance data (Gilmanov et al. 2007). By contrast, in cut grasslands, biomass is exported off site and neither this carbon export nor the import of carbon from organic fertilisers is detected by the atmospheric budget. Therefore, accounting for exports and imports of organic carbon is essential to compare cut and grazed grasslands in terms of their net carbon storage (net biome productivity, NBP) (Yazaki et al. 2004) (Fig. 13.1). Numerous studies should be reanalysed following this precept (Novick et al. 2004; Rogiers et al. 2005).

In order to calculate NBP, Soussana et al. (2007) have adapted the definition of Chapin et al. (2002) to a managed grassland:

$$
\mathrm{NBP}=\mathrm{NEE}-F_{\text {import }}+F_{\text {harvest }}+F_{\mathrm{CH}_{4}}+F_{\mathrm{LW}}+F_{\text {leach }}
$$

where $F_{\text {harvest }}$ is the $\mathrm{C}$ lost from the system through plant biomass export (mowing), $F_{\text {import }}$ the flux of $\mathrm{C}$ entering the system through manure and/or slurry application, $F_{\mathrm{CH} 4}$ the $\mathrm{C}$ lost through $\mathrm{CH}_{4}$ emissions by grazing cattle, $F_{\mathrm{LW}}$ the $\mathrm{C}$ lost from the system through animal body mass increase and milk production and $F_{\text {leach }}$ the $\mathrm{C}$ lost through dissolved organic/inorganic $\mathrm{C}$ leaching.

Within the GreenGrass project, the full GHG balance of nine contrasted grassland sites covering a major climatic gradient over Europe was measured during 2 complete years (Soussana et al. 2007). The sites include a wide range of management regimes (rotational grazing, continuous grazing and mowing), the three main types of managed grasslands across Europe (sown, intensive permanent and seminatural grassland) and contrasted nitrogen fertiliser supplies. At all sites, the NEE of $\mathrm{CO}_{2}$ was assessed using the eddy covariance technique. $\mathrm{N}_{2} \mathrm{O}$ emissions were monitored using various techniques (GC-cuvette systems, automated chambers and tunable diode laser) and $\mathrm{CH}_{4}$ emissions resulting from enteric fermentation of the grazing cattle were measured in situ at four sites using the $\mathrm{SF}_{6}$ tracer method.

Averaged over the two measurement years, NEE results show that the nine grassland plots displayed a net sink for atmospheric $\mathrm{CO}_{2}$ of $240 \pm 70 \mathrm{~g} \mathrm{C} \mathrm{m}^{-2}$ year ${ }^{-1}$ (mean \pm confidence interval at $p>0.95$ ) (Soussana et al. 2007). The average $\mathrm{C}$ storage (NBP) was estimated at $-104 \pm 73 \mathrm{~g} \mathrm{C} \mathrm{m}^{-2} \mathrm{year}^{-1}$, that is $45 \%$ of the atmospheric $\mathrm{CO}_{2}$ sink. This discrepancy can be explained, since more organic $\mathrm{C}$ was harvested 


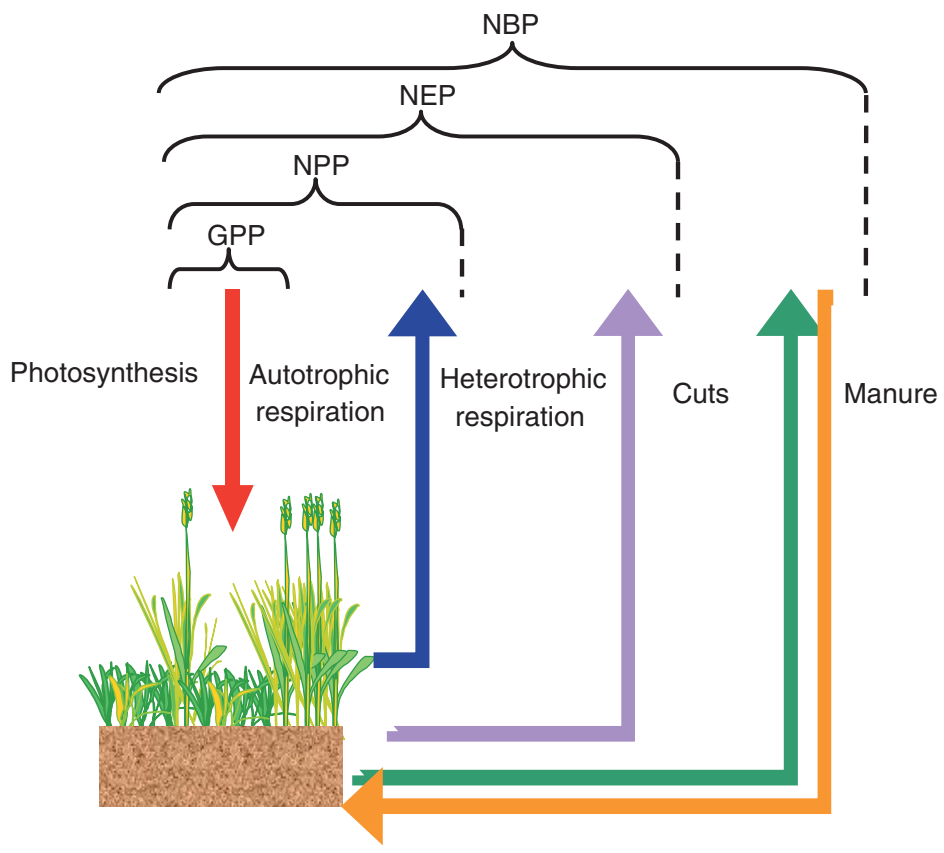

Fig. 13.1 C fluxes in a managed grassland system with imports (manure application) and exports (cuts and harvests) of organic carbon. GPP, gross primary productivity; NPP, net primary productivity; NEP, net ecosystem productivity; NBP, net biome productivity (See Color Plate 5).

from, than returned to, the grassland plots (Soussana et al. 2007). Such results show that the balance of horizontal fluxes of organic carbon (exports by mowing and imports by manure spreading) needs to be accurately measured in eddy flux sites in order to be able to estimate the plot scale carbon storage in managed grasslands.

Quite often not all components of the NBP budget are measured. For example, dissolved organic/inorganic C (DOC/DIC) losses as well as C exports in milk and meat products are sometimes neglected. Siemens and Janssens (2003) have estimated at the European scale the average DOC/DIC loss at $11 \pm 8 \mathrm{~g} \mathrm{~m}^{-2}$ year $^{-1}$. Assuming a value at the upper range of this estimate would reduce the grassland NBP by $20 \%$. In contrast, the role of organic C exports is relatively small with meat production systems (e.g. 1.6\% of NBP, Allard et al. 2007) but can be higher with intensive dairy production systems.

The selection of sites is crucial for any network and may induce a bias (Körner 2003). In Europe, most agriculturally managed grasslands are used according to a production potential that is partly determined by local climate conditions. Therefore, $\mathrm{N}$ fertiliser supply, manure spreading and forage harvests tend to scale with the length of the herbage growing season (Soussana et al. 2007). This creates a confounding effect between climate and management and reduces our ability to fully understand the determinants of field scale carbon storage in grasslands. Moreover, 
the long-term history of land use and land management is usually not known in eddy covariance grassland sites. This is also a major limitation as soil respiration is affected by long-term changes in SOC pools as a result of past changes in land use and land management. Mechanistic modelling is needed to overcome these limits and assess the role of both management variables and site history for $\mathrm{C}$ fluxes (Soussana et al. 2004b).

\subsubsection{Net Greenhouse Gas Exchange}

Budgeting equations can be extended to include fluxes $\left(F_{\mathrm{CH}_{4}}\right.$ and $\left.F_{\mathrm{N} 2 \mathrm{O}}\right)$ of non- $\mathrm{CO}_{2}$ radiatively active trace gases and calculate a net exchange rate in $\mathrm{CO}_{2}-\mathrm{C}$ equivalents (13.2), using the global warming potential (GWP) of each gas at the 100 years time horizon (IPCC 2001b):

$$
\mathrm{NGHGE}=\mathrm{NEE}+F_{\mathrm{CH}_{4}} \cdot \mathrm{GWP}_{\mathrm{CH}_{4}}+F_{\mathrm{N}_{2} \mathrm{O}} \cdot \mathrm{GWP}_{\mathrm{N}_{2} \mathrm{O}}
$$

where

$$
\begin{gathered}
\mathrm{GWP}_{\mathrm{N}_{2} \mathrm{O}}=127 \text {, as } 1 \mathrm{~kg} \mathrm{~N}_{2} \mathrm{O}-\mathrm{N}=127 \mathrm{kgCO}_{2}-\mathrm{C} \\
\mathrm{GWP}_{\mathrm{CH}_{4}}=8.36 \text {, as } 1 \mathrm{kgCH}_{4}-\mathrm{C}=8.36 \mathrm{kgCO}_{2}-\mathrm{C} .
\end{gathered}
$$

In order to account for (1) the off-site $\mathrm{CO}_{2}$ and $\mathrm{CH}_{4}$ emissions resulting directly from the digestion by cattle of the forage harvests and (2) the manure and slurry applications which add organic $\mathrm{C}$ to the soil, an attributed net greenhouse gas balance (NGHGB) was calculated by Soussana et al. (2007) as:

$$
\mathrm{NGHGB}=\mathrm{NGHGE}+F_{\text {harvest }} \cdot\left(k_{\text {digest }}+k_{\mathrm{CH}_{4}} \cdot \mathrm{GWP}_{\mathrm{CH}_{4}}\right)
$$

where $k_{\text {digest }}$ is the proportion of the ingested $\mathrm{C}$ that is digestible and hence will be respired by ruminants and $k_{\mathrm{CH} 4}$ the fraction of the ingested $\mathrm{C}$ emitted as $\mathrm{CH}_{4}$ from enteric fermentation.

On average of the nine sites covered by the 'GreenGrass' European project, the grassland plots displayed annual $\mathrm{N}_{2} \mathrm{O}$ and $\mathrm{CH}_{4}$ emissions of $14 \pm 5$ and $32 \pm 7 \mathrm{~g}$ $\mathrm{CO}_{2}-\mathrm{C}$ equivalents $\mathrm{m}^{-2}$ year ${ }^{-1}$, respectively. Hence, when expressed in $\mathrm{CO}_{2}-\mathrm{C}$ equivalents, emissions of $\mathrm{N}_{2} \mathrm{O}$ and $\mathrm{CH}_{4}$ resulted in a $19 \%$ reduction of the NEE sink activity. The attributed $\mathrm{GHG}$ balance was, however, not significantly different from zero $\left(-85 \pm 77 \mathrm{~g} \mathrm{CO}_{2}-\mathrm{C}\right.$ equivalents $\mathrm{m}^{-2}$ year $\left.^{-1}\right)$. The net exchanges by the grassland ecosystems of $\mathrm{CO}_{2}$ and of GHG were highly correlated with the difference in carbon used by grazing versus cutting, indicating that cut grasslands have a greater on-site sink activity than grazed grasslands. However, the NBP was significantly correlated to the total $\mathrm{C}$ used by grazing and cutting, indicating that, on average, net carbon storage declines with herbage utilisation by herbivores (Soussana et al. 2007). 
Taken together, these results show that European grasslands are likely to act as relatively large atmospheric $\mathrm{CO}_{2}$ sinks. By contrast to forests, approximately half of the sink activity is stored in labile carbon pools (i.e. forage), which will be digested within 1 year by herbivores. When expressed in $\mathrm{CO}_{2}-\mathrm{C}$ equivalents, on-site $\mathrm{N}_{2} \mathrm{O}$ and $\mathrm{CH}_{4}$ emissions from grassland plots would apparently not compensate the atmospheric $\mathrm{CO}_{2}$ sink activity. Nevertheless, the off-site digestion by livestock of the harvested herbage leads to additional emissions of $\mathrm{CO}_{2}$ and $\mathrm{CH}_{4}$ which would offset the net GHG sink activity of the grassland plots. These first conclusions are, however, based on a small number of sites and of years. More efforts are clearly needed in order to further reduce the uncertainties in the carbon and GHG budgets in each site, and to reach an optimum number of sites (see below).

\subsection{Farm Scale}

A grazing livestock farm consists of a productive unit that converts various resources into outputs as milk, meat and sometimes grains too. In Europe, many ruminant farms have mixed farming systems: they produce themselves the roughage and, most often, part of the animal's feeds and even straw that is eventually needed for bedding. Conversely, these farms recycle animal manure by field application. Most farms purchase some inputs as fertilisers and they always use direct energy derived from fossil fuels. The net emissions of GHGs (methane, nitrous oxide and carbon dioxide) are related to carbon and nitrogen flows and to environmental conditions.

Until now, there are only few recent models of the farm GHG balance. Most models have used fixed emission factors for both indoors and outdoors emissions (e.g. FARM GHG Olesen et al., 2006; CNFarm Schils et al. 2005; Lovett et al. 2006). Although, these models have considered the on and off farm $\mathrm{CO}_{2}$ emissions (e.g. from fossil fuel combustion), they did not include possible changes in soil $\mathrm{C}$ resulting from the farm management. Moreover, as static factors are used rather than dynamic simulations, the environmental dependency of the GHG fluxes is not captured by these models.

A dynamic farm scale model called FarmSim has been developed within the framework of the European 'GreenGrass' project. It consists of nine interacting modules concerning the farm structure (area and type of grasslands and of annual crops, herd types), the soils, the meteorology, the grassland management (grazing and cutting dates, stocking rates, organic and inorganic fertiliser applications), the annual crops management, the herd (number of animals per type each fortnight), the feeding system and the waste management system. FarmSim simulates the herbage productivity and greenhouse gas (GHG) balance of each grassland plot using the mechanistic Pasim (Riedo et al. 1998) model. Contrasted scenarios concerning the net organic $\mathrm{C}$ storage of both grassland and cropland plots are compared. The IPCC methodology Tier 1 and Tier 2 is used to calculate the $\mathrm{CH}_{4}$ and $\mathrm{N}_{2} \mathrm{O}$ emissions from annual crops and cattle housing. The net GHG balance at the farm 
gate is calculated in $\mathrm{CO}_{2}$ equivalents. Emissions induced by the production and transport of major farm inputs (fuel, electricity, $\mathrm{N}$ fertilisers and feedstuffs) are calculated using a full accounting scheme based on life cycle analysis. The FarmSim model has been applied to seven contrasted cattle farms in Europe (Salètes et al. 2004). The balance of the farm gate GHG fluxes leads to a sink activity for four of the seven farms. When including pre-chain emissions related to inputs, all farms but one were found to be net sources of GHG. The total farm GHG balance varied between a sink of -70 and a source of $+310 \mathrm{~kg} \mathrm{CO}_{2}$ equivalents per unit (GJ) energy in animal farm products. As with other farm scale models, the annual farm $\mathrm{N}$ balance was the single best predictor of the farm GHG budget (Schils et al. in press).

The short-term $\mathrm{C}$ cycling has sometimes been neglected as the $\mathrm{C}$ exchanged with the atmosphere is of biological origin and, hence, is not included in the IPCC methodology. Nevertheless, the atmospheric $\mathrm{CO}_{2}$ balance at the farm scale is essential for scaling up from the plot to the farm and then to the landscape. Directly scaling the measured NEE of grassland plots up to the regional scale would be misleading in terms of net C storage, since: (1) the NBP (net C storage at the field scale) is much lower than the NEE (see 2.3), and (2) livestock farms may import and export organic $\mathrm{C}$ in the form of straw, roughage, concentrate feeds and manure, which means that the farm scale net $\mathrm{C}$ storage will not be equal to the atmospheric $\mathrm{CO}_{2}$ balance.

\subsection{Regional Scale}

Grasslands and rangelands management in Europe varies with the duration of the plant cover (e.g. sown vs. long-term grasslands), the grazing and mowing patterns, as well as the fertiliser supply, irrigation and drainage. This diversity makes direct comparison among sites or direct upscaling difficult.

A grassland typology was developed for carbon inventories by the IPCC (2004). This typology separates degraded grasslands (e.g. overgrazed, less productive ...), nominally managed (e.g. pasture and rangelands with no grazing problems or inputs, native vegetation) and improved grasslands with medium/high inputs (e.g. sown grasses and legumes, fertiliser supply, liming, irrigation). While these general categories are useful, they need to be adapted in each region, taking into account not only the soil and vegetation types but also the animal stocking density, the organic and inorganic fertiliser application and the number and timing of harvests.

Georeferenced data on small regions need to be obtained every 5-10 years, including the area of grasslands per type, the management data for each grassland type and estimates of the total below and above-ground organic carbon content per grassland type. Therefore, a key message is the need to develop improved systems for the collection of georeferenced statistics on types and timing of agricultural management events for grasslands, information which is currently missing from most national and European statistics (Soussana et al. 2004b). 
Grassland productivity should also be known, since regional or sectoral budgets often require knowledge of crop growth or yields. However, in contrast with arable crops, there are very few statistics available for grassland productivity. Proxies such as the animal stocking density per unit grassland/rangeland area can be calculated. Nevertheless, in intensive livestock breeding areas, the diet of domestic herbivores includes a large fraction of concentrate feeds and roughage, inputs that are purchased rather than produced on farm. Hence, there is no direct relationship between the animal stocking density, as estimated from regional statistics, and the actual grazing pressure (Soussana et al. 2004b). Given the numerous shortcomings of regional budget methods, an upscaling methodology based on models tested at benchmark sites is an attractive alternative.

Carefully parametrised and evaluated process-based models allow extrapolating flux data to the regional scale. However, there have been only few attempts to estimate the net radiative forcing fluxes of European grasslands by mechanistic modelling. Vuichard et al. (2007a, b) have used a process-oriented model (PaSim, Riedo et al. 1998) to account explicitly for edaphic, climatic and management variability over Europe. The distribution of management practices (grazing vs. cutting, cut events, animal density) is simulated to match biological constraints rather than economic ones. This study assumed that the management in each grid point reflects the capacity of grasslands to optimally sustain animals through grazing and feeding on locally harvested forage. In other words, macro- and microeconomical and cultural forces were assumed to be of second order compared to biological constraints. Despite these somewhat simplistic assumptions, rather realistic values of seasonal leaf area index, forage yields, livestock numbers, $\mathrm{CH}_{4}$ and $\mathrm{N}_{2} \mathrm{O}$ emissions were found.

The management scheme developed by Vuichard et al. (2007b) assumes an optimal grassland use, whereas in Europe, economic factors are quite strong (subsidies, cost of fertilisers, revenue of animals products ...). For example, extensive use of grasslands which tends to be common in some mountain regions in Europe (Marriott et al. 2004) was not simulated. Simulation results have shown that the GHG budget may vary from a sink to a source for any $\mathrm{N}$ fertilisation scenario depending on the current compared to long-term equilibrium $\mathrm{C}$ stocks in the soil (Vuichard et al. 2007b). This result underlines that the changes in soil organic $\mathrm{C}$ content, as affected by global (elevated $\mathrm{CO}_{2}$, climate change and $\mathrm{N}$ deposition) and local (fertiliser application, grazing and mowing patterns, irrigation) drivers are a key for the GHG balance of European grasslands.

Data from the National Soil Inventory of England and Wales obtained between 1978 and 2003 (Bellamy et al. 2005) show that carbon was lost from top soils across England and Wales over the survey period at a mean rate of $0.6 \%$ year $^{-1}$ (relative to the existing soil carbon content). The relative rate of carbon loss increased with soil carbon content and was more than $2 \%$ year $^{-1}$ in soils with carbon contents greater than $100 \mathrm{~g} \mathrm{~kg}^{-1}$. The relationship between rate of carbon loss and carbon content is irrespective of land use, suggesting a link to climate change (Bellamy et al. 2005). 
The possible implication of climate change was further studied by Smith et al. (2005) who calculated soil carbon change using the Rothamsted carbon model and using climate data from four global climate models implementing four IPCC emission scenarios (SRES). Changes in net primary production (NPP) were calculated by the Lund-Potsdam-Jena model. Land use change scenarios were used to project changes in cropland and grassland areas. Projections for 1990-2080 for mineral soil show that climate effects (soil temperature and moisture) will tend to speed decomposition and cause soil carbon stocks to decrease, whereas increases in carbon input because of increasing NPP will slow the loss. Technological improvement may further increase carbon inputs to the soil. When incorporating all factors, for grassland soils, Smith et al. (2005) have found a small increase (3-6 tC ha-1) in soil carbon on a per area basis under future climate.

\subsection{Conclusions}

The role of global (i.e. global warming, atmospheric $\mathrm{CO}_{2}$ rise and $\mathrm{N}$ deposition) environmental factors versus local land use and land management factors for $\mathrm{C}$ sequestration by European grasslands is still unclear. The development of a longterm monitoring strategy of these managed ecosystems is crucial in order to understand how climate variability, climatic and atmospheric changes affect ecosystem productivity, carbon stocks and GHG fluxes. Several criteria should be met for ensuring the success of such a monitoring strategy.

Apart from generic data quality and site representativity criteria, specific requirements for grassland sites concern:

1. Grassland management. Most grassland sites are managed for agricultural or nature conservation goals. While some flexibility is needed to cope with climate variability, clear guidelines need to be established to avoid possible confounding effects of management changes for soil pools and for $\mathrm{CO}_{2}$ and $\mathrm{GHG}$ fluxes. Moreover, the management needs to reflect standard regional practices, while avoiding unnecessary complexity (e.g. mixing herbivore types, mixing different plots in the footprint of the mast, ...) which may prevent model calibration and evaluation.

2. All components of the $\mathrm{C}$ cycle and of the GHG emissions need to be studied. The hidden parts of the $\mathrm{C}$ cycle (imports and exports of organic carbon, $\mathrm{CH}_{4}$ emissions, DOC and DIC losses, ...) need to receive due attention, since they have a key role for net carbon storage rate (NBP). While it may not be possible to study all components of the $\mathrm{C}$ cycle at the same time, the role of the missing components of the budget needs to be estimated preferably through short-term campaigns, or at least through literature checks to constrain the uncertainties. In the same way, major sources of non- $\mathrm{CO}_{2}$ trace gases $\left(\mathrm{N}_{2} \mathrm{O}, \mathrm{CH}_{4}\right)$ need to be measured, and as far as possible other indirect sources (e.g. $\mathrm{NO}_{3}^{-}, \mathrm{NH}_{3}, \mathrm{NO}_{x}$ ) should be estimated. This is especially important in intensively managed grasslands, given the major role of non- $\mathrm{CO}_{2}$ emissions for the GHG balance of these systems. 
3. Ecosystem monitoring. A number of biotic interactions (plant-plant, plant-soil biota, plant-herbivore, ...) affect ecosystem processes and C cycling in grasslands. Carefully monitoring the major state variables of the vegetation and soil compartments is a pre-requisite for model evaluation. However, there are many practical problems associated with the monitoring of a grazed pasture, such as fast plant tissue turnover, large spatial heterogeneity of the soil and vegetation and large changes in phenology and herbage mass within a few weeks only. Moreover, the functional role of the plant species diversity (Loreau et al. 2001) and dynamics (Lavorel and Garnier 2002; Louault et al. 2005) has not yet been included in ecosystem models which limits their predictive ability. Advanced models linking community and ecosystem ecology will be needed for $\mathrm{C}$ cycle modelling in semi-natural grasslands. To test such models at long-term flux monitoring sites, plant community structure data will be required.

While the development of a strong grassland site network and the advancement of models are important pre-requisites for a full accounting of the GHG balance at European scale, a third major component, which is currently missing, concerns georeferenced data of grassland types and grassland management. Given the major role of organic $\mathrm{C}$ fluxes in livestock farms (exports of forages from grassland plots and imports of manures, purchase of concentrate feed and roughage), grassland and farm typologies should be linked in order to allow for the calculation of the $\mathrm{C}$ balance of livestock farms. This approach would allow keeping track of changes as influenced by socio-economic trends and would help designing mitigation options that are relevant for farmers.

\section{References}

Aeschlimann, U., Nösberger, J., Edwards, P.J., Schneider, M.K., Richter, M., and Blum, H. 2005. Responses of net ecosystem $\mathrm{CO}_{2}$ exchange in managed grassland to long-term $\mathrm{CO}_{2}$ enrichment, $\mathrm{N}$ fertilization and plant species. Plant, Cell and Environment 28:823-833.

Allard, V., Soussana, J.F., Falcimagne, R., Berbigier, P., Bonnefond, J.M., Ceschia, E., et al. 2007. The role of grazing management for the net biome productivity and greenhouse gas budget $\left(\mathrm{CO}_{2}\right.$, $\mathrm{N}_{2} \mathrm{O}$ and $\mathrm{CH}_{4}$ ) of semi-natural grassland. Agriculture, Ecosystems and Environment 121:47-58.

Baldocchi, D., and Meyers, T. 1998. On using eco-physiological, micrometeorological and biogeochemical theory to evaluate carbon dioxide, water vapor and trace gas fluxes over vegetation: A perspective. Agriculture and Forest Meteorology 90:1-25.

Baldocchi, D., Valentini, R., Running, S., Oechel, W., and Dahlman, R. 1996. Strategies for measuring and modelling carbon dioxide and water vapor fluxes over terrestrial ecosystems. Global Change Biology 2:159-168.

Balesdent, J., and Balabane, M. 1996. Major contribution of roots to soil carbon storage inferred from maize cultivated soils. Soil Biology and Biochemistry 28:1261-1263.

Bellamy, P.H., Loveland, P.J., Bradley, R.I., Lark, R.M., and Kirk, G.J.D. 2005. Carbon losses from all soils across England and Wales 1978-2003. Nature 437:245-248.

Bird, S.B., Herrick, J.E., Wander, M.M., and Wright, S.F. 2002. Spatial heterogeneity of aggregate stability and soil carbon in semi-arid rangeland. Environmental Pollution 116:445-455.

Blaxter, K.L., and Clapperton, J.L. 1965. Prediction of the amount of methane produced by ruminants. British Journal of Nutrition 19:511-522. 
Boeckx, P., and Van Cleemput, O. 2001. Estimates of $\mathrm{N}_{2} \mathrm{O}$ and $\mathrm{CH}_{4}$ fluxes from agricultural land in various regions of Europe. Nutrient Cycling in Agroecosystems 60:35-47.

Bouwman, A.F. 1996. Direct emission of nitrous oxide from agricultural soils. Nutrient Cycling in Agroecosystems 46:53-70.

Cannell, M.G.R., Milne, R., et al. 1999. National inventories of terrestrial carbon sources and sinks, the UK experience. Climate Change 42.

CarboEurope IP 2003. Assessment of the European Terrestrial Carbon Balance. Integrated Project. Sixth Framework Programme. Priority 1.1.6.3 Global Change and Ecosystems.

Carlier, L., De Vliegher, A., van Cleemput, O., and Boeckx, P. 2004. Importance and functions of European grasslands. Proceedings of the COST Action 627 "Carbon storage in European Grasslands", Ghent, 3-6 June 2004, pp. 7-16.

Casella, E., and Soussana, J.F. 1997. Long-term effect of $\mathrm{CO}_{2}$ enrichment and temperature increase on the carbon balance of a temperate grass sward. Journal of Experimental Botany 48:1309-1321.

Cernusca, A. (Project co-ordinator) 2004. Official project web site: CARBOMONT: http://botany. uibk.ac.at/forschung/forschungsprojekte/carbomont_ordner/carbomont/

Chapin, F.S. III, Matson, P.A., and Mooney, H.A. 2002. Principles of Terrestrial Ecosystem Ecology. Springer, New York.

Chevallier, T., Voltz, M., Blanchart, E., Chotte, J.L., Eschenbrenner, V., Mahieu, M., and Albrecht, A. 2000. Spatial and temporal changes of soil $\mathrm{C}$ after establishment of a pasture on a long-term cultivated vertisol (Martinique). Geoderma 94:43-58.

Ciais, P., Reichstein, M., Viovy, N., Granier, A., Ogee, J., Allard, V., Aubinet, M., Buchmann, N., et al. 2005. Europe-wide reduction in primary productivity caused by the heat and drought in 2003. Nature 437:529-533.

Clayton, H., McTaggart, I.P., Parker, J., Swan, L., and Smith, K.A. 1997. Nitrous oxide emissions from fertilised grassland: A 2-year study of the effects of $\mathrm{N}$ fertiliser form and environmental conditions. Biology and Fertility of Soils 25:252-260.

Conant, R.T., Paustian, K., and Elliott, E.T. 2001. Grassland management and conversion into grassland: Effects on soil carbon. Ecological Applications 11:343-355.

CORINE 1995. CORINE land cover-Part 1: Methodology. EEA technical report.

CORINE 2000. Addendum to the land cover technical guide. EEA technical report.

Delgado, C.L. 2005. Rising demand for meat and milk production in developing countries: Implications for grasslands-based livestock production. In: McGilloway (Ed.), Grassland: A Global Resource, pp. 29-41. Wageningen Acad. Publisher. ISBN907699871X.

De Mazancourt, C., Loreau, M., and Abbadie, L. 1998. Grazing optimization and nutrient cycling: When do herbivores enhance plant production? Ecology 79:2242-2252.

Dueck, T.A., de Visser, R., Poorter, H., Persijn, S., Gorissen, A., de Visser, W., et al. 2007. No evidence for substantial aerobic methane emission by terrestrial plants: $\mathrm{A}{ }^{13} \mathrm{C}$-labelling approach. New Phytologist, doi: 10.1111/j.1469-8137.2007.02103.x.

Hendriks, D.M.D., van Huissteden, J., Dolman, A.J., and van der Molen, M.K. 2007. The full greenhouse gas balance of an abandoned peat meadow. Biogeosciences 4:411-424.

European Environment Agency (EEA) 2005. The European Environment: State and outlook 2005. Part A. Integrated assessment 245 pp. EEA.

Food and Agricultural Organisation (FAO) 2004. FAOSTAT data, FAO.

Flechard, C.R., Neftel, A., Jocher, M., Ammann, C., and Fuhrer, J. 2005. Bi-directional soil/ atmosphere $\mathrm{N}_{2} \mathrm{O}$ exchange over two mown grassland systems with contrasting management practices. Global Change Biology 11:2114-2127.

Flechard, C.R., Ambus, P., Skiba, U., Rees, R.M., Hensen, A., van den Pol, A., Soussana, J.-F., et al. 2007. Effects of climate and management intensity on nitrous oxide emissions in grassland systems across Europe. Agriculture Ecosystems and Environment 121:135-152.

Follett, R.F. 2001. Organic carbon pools in grazing land soils. In: Follett, R.F., Kimble, J.M., and Lal, R. (Eds.), Potential of US Grazing Lands to Sequester Carbon and Mitigate the Greenhouse Effect, pp. 65-86. Lewis Publishers Inc., Boca Raton.

Freibauer, A., Rounsevell, M.D.A., Smith, P., and Verhagen, J. 2004. Carbon sequestration in the agricultural soils of Europe. Geoderma 122:1-23. 
Giger-Reverdin, S., Sauvant, D., Vermorel, M., and Jouany, J.P. 2000. Modélisation empirique des facteurs de variation des rejets de méthane par les ruminants. Rencontre Recherche Ruminants 7:187-190.

Gilmanov, T.G., Tieszen, L.L., Wylie, B.K.,Flanagan, L.B., Frank, A.B., Haferkamp, M.R., Meyers, T.P., and Morgan, J.A. 2005. Integration of $\mathrm{CO}_{2}$ flux and remotely-sensed data for primary production and ecosystem respiration analyses in the Northern Great Plains: Potential for quantitative spatial extrapolation. Global Ecology and Biogeography 14:271-292.

Gilmanov, T., Soussana, J.F., Aires, L., Allard, V., Ammann, C., Balzarolo, M., Barcza, Z., Bernhofer, C., Campbell, C.L., Cernusca, A., et al. 2007. Partitioning of the tower-based net $\mathrm{CO}_{2}$ exchange in European grasslands into gross primary productivity and ecosystem respiration components using light response functions analysis 2007. Agriculture, Ecosystems and Environment 121:93-120.

INRA 2002. In: Arrouays, D., Balesdent, J., Germon, J.C., Jayet, P.A., Soussana, J.F., and Stengel, P. (Eds.), Contribution à la lutte contre l'effet de serre. Stocker du carbone dans les sols agricoles de France? Institut National de la Recherche Agronomique (INRA), 147 rue de l'Université, Paris. ISBN 2-7380-1054-7.

IPCC 1996a. Revised guidelines for national greenhouse gas inventories. Intergovernmental Panel on Climate Change, IPCC, Cambridge University Press.

IPCC 1996b. Climate change 1995. The science of climate change. Contribution of working group I to the 2nd assessment report of the IPCC. Intergovernmental Panel on Climate Change, Cambridge University Press.

IPCC 2001a. Climate change 2001: The scientific basis (contribution of working group I to the third assessment report of the Intergovernmental Panel on Climate Change). Intergovernmental Panel on Climate Change, Cambridge University Press.

IPCC 2001b. Good practice guidance and uncertainty management in national greenhouse gas inventories. Intergovernmental Panel on Climate Change (IPCC), Institute for Global Environmental Strategies, Tokyo, Japan.

IPCC 2004. Good practice guidance on land use change and forestry in national greenhouse gas inventories. Intergovernmental Panel on Climate Change (IPCC), Institute for Global Environmental Strategies, Tokyo, Japan.

Janssens, I.A., Freibauer, A., Ciais, P., Smith, P., Nabuurs, G.-J., Folberth, G., Schlamadinger, B., Hutjes, R.W.A., Ceulemans, R., Schulze, E.-D., Valentini, R., and Dolman, A.J., 2003. Europe's biosphere absorbs $7-12 \%$ of anthrogogenic carbon emissions. Science 300:1538-1542.

Johnson, K., Huyler, M., Westberg, H., Lamb, B., and Zimmerman, P. 1994. Measurement of methane emissions from ruminant livestock using a SF6 tracer technique. Environmental Science and Technology 28:359-362.

Jones, M.B., and Donnelly, A. 2004. Carbon sequestration in temperate grassland ecosystems and the influence of management, climate and elevated $\mathrm{CO}_{2}$. New Phytologist 164:423-439.

Keppler, F., Hamilton, J.T.G., Brass, M., and Rockmann, T. 2006. Methane emissions from terrestrial plants under aerobic conditions. Nature 439:187-191.

Körner, C. 2003. Atmospheric science: Slow in, rapid out—Carbon flux studies and Kyoto targets. Science 300:1242-1243.

Lal, R. 2004. Soil carbon sequestration impacts on global climate change and food security. Science 304:1623-1627.

Lavorel, S., and Garnier, E. 2002. Predicting changes in community composition and ecosystem functioning from plant traits: Revisiting the Holy Grail. Functional Ecology 16:545-556.

Leahy, P., Kiely, G., and Scanlon, T.M. 2004. Managed grasslands: A greenhouse gas sink or source? Geophysical Research Letters 31, L20507, doi:10.1029/2004GL021161.

Lemaire, G., and Chapman, D. 1996. Tissue flows in grazed plant communities. In: Hodgson, J., Illius, A.W. (Eds.), The Ecology and Management of Grazing Systems. CABI, Wallingford.

Loreau, M., Naeem, S., Inchausti, P., Bengtsson, J., Grime, J.P., Hector, A., Hooper, D.U., Huston, M.A., Raffaelli, D., Schmid, B., Tilman, D., and Wardle, D.A. 2001. Biodiversity and ecosystem functioning: Current knowledge and future challenges. Science 294:804-808. 
Louault, F., Pillar, V.D., Aufrere, J., Garnier, E., and Soussana, J.F. 2005. Plant traits functional types in response to reduced disturbance in a semi-natural grassland. Journal of Vegetation Science 16:151-160.

Lovett, D.K., Shalhoo, L., Dillon, P., and O'Mara, F.P. 2006. A systems approach to quantify greenhouse gas fluxes from pastoral dairy production as affected by management regimes. Agricultural Systems 88:156-179.

Machefert, S.E., Dise, N.B., Goulding, K.W.T., and Whitehead, P.G. 2002. Nitrous oxide emission from a range of land uses across Europe. Hydrology and Earth System Sciences 6:325-337.

Marriott, C.A., Fothergill, M., Jeangros, B., Scotton, M., and Louault, F. 2004. Long-term impacts of extensification of grassland management on biodiversity and productivity in upland areas. A review. Agronomie 24:447-462.

Novick, K., Stoy, P., Katul, G., Ellsworth, D., Siqueira, M., Juang, J., and Joren, R. 2004. Carbon dioxide and water vapor exchange in a warm temperate grassland. Oecologia 138:259-274.

Ogle, S.M., Conant, R.T., and Paustian, K. 2004. Deriving grassland management factors for a carbon accounting approach developed by the Intergovernmental Panel on Climate Change. Environmental Management 33:474-484.

Olesen, J.E., Schelde, K., Weiske, A., Weisbjerg, M.R., Asman, W.A.H., and Djurhuus, J. 2006. Modelling greenhouse gas emissions from European conventional and organic dairy farms. Agriculture, Ecosystems and Environment 112:207-220.

Paustian, K., Andrèn, O., Clarholm, M., Hansson, A.C., Johansson, G., Lagerlof, J., Lindgerg, T., Pettersson, R., and Sohlenius, B. 1990. Carbon and nitrogen budgets of four agro-ecosystems with annual and perennial crops, with and without $\mathrm{N}$ fertilization. Journal of Applied Ecology 27:60-84.

Pinares-Patino, C.S., Baumont, R., and Martin, C. 2003. Methane emissions by Charolais cows grazing a monospecific pasture of timothy at four stages of maturity. Canadian Journal of Animal Science 83:769-777.

Pinares-Patino, C.S., Dhour, P., Jouany, J.-P., and Martin, C. 2007. Effects of stocking rate on methane and carbon dioxide production by grazing cattle. Agriculture, Ecosystems and Environment 121:30-46.

Reynolds, S.G., Batello, C., Baas, S., and Mack, S. 2005. Grasslands and forage to improve livelihoods and reduce poverty. In: McGilloway (Ed.), Grassland: A Global Resource, pp. 29-41. Wageningen Acad. Publisher. ISBN907699871X.

Riedo, M., Grub, A., Rosset, M., and Fuhrer, J. 1998. A pasture simulation model for dry matter production, and fluxes of carbon, nitrogen, water and energy. Ecological Modelling 105:141-183.

Robertson, G.P., Paul, E.A., and Harwood, R.R. 2000. Greenhouse gases in intensive agriculture: Contributions of individual gases to the radiative forcing of the atmosphere. Science 289:1922-1925.

Robles, M.D., and Burke, I.C. 1998. Soil organic matter recovery on Conservation Reserve Program fields in southeastern Wyoming. Soil Science Society of America Journal 62:725-730.

Rogiers, N., Eugster, W., Furger, M., and Siegwolf, R. 2005. Effect of land management on ecosystem carbon fluxes at a subalpine grassland site in the Swiss Alps. Theoretical and Applied Climatology 80:187-203.

Salètes, S., Fiorelli, J.L., Vuichard, N., Cambou, J., Olesen, J.E., Hacala, S., Sutton, M., Furhrer, J., and Soussana, J.F. 2004. Greenhouse gas balance of cattle breeding farms and assessment of mitigation option. In: Greenhouse Gas Emissions from Agriculture Conference. Leipzig, Germany 203-208 (10-12 February 2004).

Schils, R.L.M., Verhagen, A., Aarts, H.F.M., and Šebek, L.B.J. 2005. A farm level approach to define successful mitigation strategies for greenhouse gas emissions from ruminant livestock systems. Nutrient Cycling in Agroecosystems 71:163-175.

Schils, R.L.M., Olesen, J.E., del Prado, A., and Soussana, J.F. in press. A farm level modelling approach for mitigating greenhouse gas emissions from ruminant livestock systems. Livestock Science 112: 240-251.

Siemens, J., and Janssens, I.A. 2003. The European carbon budget: A gap. Science 302:1681. 
Smith, P., Goulding, K.W.T., Smith, K.A., Powlson, D.S., Smith, J.U., Falloon, P.D., and Coleman, K. 2001. Enhancing the carbon sink in European agricultural soils: Including trace gas fluxes in estimates of carbon mitigation potential. Nutrient Cycling in Agroecosystems 60:237-252.

Smith, J., Smith, P., Wattenbach, M., Zaehle, Z., Hiederer, R., Jones, R.A., Montanarella, L., Rounsevell, M.D.A., Reginsters, I., and Ewert, F. 2005. Projected changes in mineral soil carbon of European croplands and grasslands, 1990-2080. Global Change Biology 11:2141-2152.

Sommer, S.G., Petersen, S.O., and Møller, H.B. 2004. Algorithms for calculating methane and nitrous oxide emissions from manure management. Nutrient Cycling in Agroecosystems 69:143-154.

Soussana, J.F., Loiseau, P., Vuichard, N., Ceschia, E., Balesdent, J., Chevallier, T., and Arrouays, D. 2004a. Carbon cycling and sequestration opportunities in temperate grasslands. Soil Use and Management 20:219-230.

Soussana, J.F., Salètes, S., Smith, P., Schils, R., and Ogle, S. 2004b. Greenhouse gas emissions from European grasslands. In: Sezzi, E., Valentini, R. (Eds.), Report 4/2004, Specific Study 3, CarboEurope GHG, Concerted Action, Synthesis of the European Greenhouse Gas Budget. University of Tuscia, Viterbo, Italy. ISSN1723-2236.

Soussana, J.F., Allard, V., Pilegaard, K., Ambus, P., Ammann, C., Campbell, C., Ceschia, E., Clifton-Brown, J., et al. 2007. Full accounting of the greenhouse gas $\left(\mathrm{CO}_{2}, \mathrm{~N}_{2} \mathrm{O}, \mathrm{CH}_{4}\right)$ budget of nine European grassland sites. Agriculture, Ecosystems and Environment 121:121-134.

Sozanska, M., Skiba, U., and Metcalfe, S. 2002. Developing an inventory of $\mathrm{N}_{2} \mathrm{O}$ emissions from British soils. Atmospheric Environment 36:987-998.

Van Den Pol-Van Dasselaar, A. 1998. Methane emissions from grasslands. Ph.D. Thesis, 179 pp, Wageningen University.

Velthof, G.L., and Oenema, O. 1997. Nitrous oxide emission from dairy farming systems in the Netherlands. Netherlands Journal of Agricultural Science 45:347-360.

Vermorel, M. 1995. Prédictions gazeuses et thermiques résultant des fermentations digestives. In: Jarrige, R., Ruckebusch, Y., Demarquilly, C., Farce, M. H., Journet, M., (Eds.), Nutrition des Ruminants Domestiques-Ingestion et Digestion. INRA, Paris.

Vleeshouwers, L.M., and Verhagen, A. 2002. Carbon emission and sequestration by agricultural land use: A model study for Europe. Global Change Biology 8:519-530.

Vuichard, N., Soussana, J.F., Viovy, N., Calanca, P., Clifton-Brown, J., and Ciais, P. 2007a. Estimating the greenhouse gas fluxes of European grasslands with a process-based model: 1 . Model evaluation from in situ measurements. Global Biogeochemical Cycles 21:14. GB1004. doi:10.1029/2005GB002611.

Vuichard, N., Ciais, P., Viovy, N., Calanca, P., and Soussana, J.F. 2007b. Estimating the greenhouse gas fluxes of European grasslands with a process-based model: 2. Simulations at the continental level. Global Biogeochemical Cycles 21:13. GB1005. doi:10.1029/2005GB002612.

Yazaki, Y., Mariko, S., and Koizumi, H. 2004. Carbon dynamics and budget in a Miscanthus sinensis grassland in Japan. Ecological Research 19:511-520. 